\title{
Encapsulation of lactobacillus casei into calcium pectinate-chitosan beads for enteric delivery
}

Article

Accepted Version

Bepeyeva, A., de Barros, J. M. S., Albadran, H., Kakimov, A. K., Kakimova, Z. K., Charalampopoulos, D. and Khutoryanskiy, V. (2017) Encapsulation of lactobacillus casei into calcium pectinate-chitosan beads for enteric delivery. Journal of Food Science, 82 (12). pp. 2954-2959. ISSN 0022-1147 doi: https://doi.org/10.1111/1750-3841.13974 Available at https://centaur.reading.ac.uk/73925/

It is advisable to refer to the publisher's version if you intend to cite from the work. See Guidance on citing.

Published version at: http://onlinelibrary.wiley.com/doi/10.1111/1750-3841.13974/full

To link to this article DOI: http://dx.doi.org/10.1111/1750-3841.13974

Publisher: Wiley

All outputs in CentAUR are protected by Intellectual Property Rights law, including copyright law. Copyright and IPR is retained by the creators or other copyright holders. Terms and conditions for use of this material are defined in the End User Agreement. 


\section{CentAUR}

Central Archive at the University of Reading

Reading's research outputs online 


\section{Encapsulation of Lactobacillus casei into calcium pectinate-chitosan} beads for enteric delivery

4

(6)
(1)

a Department of Standardization and Biotechnology, Shakarim State University of Semey, Semey, VKO, Kazakhstan

b Reading School of Pharmacy, University of Reading, Whiteknights, Reading, Berkshire, PO Box 224, RG6 6AD, United Kingdom

c Department of Food and Nutritional Sciences, University of Reading, Whiteknights, Reading, Berkshire, RG6 6AD United Kingdom

*Corresponding author at: Reading School of Pharmacy, University of Reading, Whiteknights, Reading, Berkshire, PO Box 224, RG6 6AD, United Kingdom. Tel.: + +44 (0) 118 378 6119; fax: +44(0) 1183784703 .

E-mail address: v.khutoryanskiy@reading.ac.uk (Prof Vitaliy V. Khutoryanskiy).

\section{ABSTRACT}

Gel beads were prepared by extrusion of various types of pectin into $0.15 \mathrm{M}$ calcium chloride. Size, morphology, and textural properties of three types of beads were evaluated and it was established that the use of $3 \mathrm{w} / \mathrm{v} \%$ amidated pectin provides the optimal characteristics suitable for encapsulation of live bacteria. Lactobacillus casei NCIMB 30185 (PXN37) was encapsulated into calcium pectinate gel through the extrusion of a live bacteria dispersion in $3 \mathrm{w} / \mathrm{v} \%$ pectin into a solution of calcium chloride. The capsules were then additionally coated with chitosan. The viability of bacteria within these capsules was studied under model gastrointestinal conditions in vitro (simulated gastric and intestinal juices). It was established that pectin-chitosan capsules can provide protection to Lactobacillus casei from the gastric acid and result in high levels of viable bacteria released in the intestine.

\section{Practical Application:}

Encapsulation of Lactobacillus casei into calcium pectinate beads coated with chitosan provided capsules capable of delivery live probiotic bacteria into the intestine. 
Key words:

Encapsulation

Lactobacillus casei

Pectin

Chitosan

Probiotic

Live bacteria

\section{Introduction}

Gastrointestinal delivery of live probiotic bacteria is considered as a promising approach to improve the gut health. Probiotics provide some health benefits due to their ability to facilitate digestion, produce vitamins, bust the immune system and prevent the growth of pathogenic bacteria (Derrien and others 2015; Reid and others 2016).

Probiotics are typically found in some dairy products; however, their successful delivery to the gut is often compromised because of the sensitivity of these bacteria to the acidic environment in the stomach (Burgain and others 2011; Cook and others 2012). Encapsulation of live probiotics into materials resistant to gastric acid is a viable strategy for their successful oral delivery. Previously, we have reported the use of calcium alginate beads coated with chitosan for encapsulation and oral delivery of Bifidobacterium species (Cook and others 2011; Cook and others 2013; Cook and others 2013; Nualkaekul and others 2013). It was established that the live bacteria encapsulated within calcium alginate beads coated with chitosan may potentially survive the transit through the harsh environment of the stomach and release high levels of live probiotic in the intestine. The protective effect of chitosan coating was found to be due to its ability to delay acid diffusion into the capsules (Cook and others 2013). It was also demonstrated that live probiotic bacteria encapsulated within calcium alginate-chitosan show excellent survival in acidic juices (Nualkaekul and others 2013) and during long storage in dry state (Albadran and others 2015).

Pectins is a group of anionic polysaccharides present in many fruits and vegetables and have a wide range of food and pharmaceutical applications as gelling, thickening, and stabilizing agents (Thakur, Singh, Handa \& Rao, 1997). They consist of several types of carbohydrate repeating units, including homogalacturonan (HG) and type I rhamnogalacturonan (RG-I). HG regions in pectins consist of poly-galacturonic acid residues; some of these are partially methyl esterified. Pectins with a high degree of methyl substitution (> 50\%) are classified as high methyl ester pectins and those with < $50 \%$ esterification are called low methyl ester pectins. Similarly to alginates, pectins are capable of forming gels upon extrusion of their aqueous solutions into the media containing soluble calcium salts 
(Morris et al, 2010). Pectin properties can also be modified by their reaction with ammonia under alkaline conditions resulting in amidated pectins. Low methyl ester amidated pectins typically require lower $\mathrm{Ca}^{2+}$ concentration to form gels and are more tolerant than low methyl ester pectin with respect to excess calcium concentrations (Belitz and others 2004).

Previously, pectins were reported as materials for encapsulation of Lactobacillus rhamnosus (Gerez and others 2012) and Lactobacillus acidophilus (Gebara and others 2013) with the subsequent coating of these capsules with whey proteins in both cases. This coating provided a protective function that ensured the effective transit of live bacteria through the gastrointestinal tract. Pectins were also used for encapsulation of probiotics in combination with other materials such as alginates (SandovalCastilla and others 2010), hyaluronic acid (Pliszczak and others 2011) and milk (Shi and others 2013). Typically the use of alginates and pectins for encapsulation of probiotics give excellent encapsulation efficiencies of 90-100\% (Shori, 2017).

In this work the ability of different pectins to form calcium gel capsules was evaluated and the most promising materials were used for encapsulation of Lactobacillus casei. The gel capsules with live probiotic were then coated with chitosan. In vitro experiments were also performed with the encapsulated probiotic bacteria to establish the protective role of chitosan coating for the successful transit of live bacteria through the gastrointestinal tract.

\section{Materials and methods}

\subsection{Materials}

Amidated pectin CU $020(63 \mathrm{kDa}$, degrees of esterification and amidation are $28 \%$ and $20 \%$, respectively), low methyl ester pectin Classic CU 701 (54 kDa and degree of esterification $36 \%$ ), high methyl pectin Classic CU-L 004/14 (67 kDa and degree of esterification 59\%) were obtained from HERBSTREITH \& Fox KG (Germany). Chitosan (103 kDa and degree of deacetylation 85.6\%), and fluorescein isothiocyanate (FITC) (isomer 1) were purchased from Sigma-Aldrich (Gillingham, U.K.). Fluorescently-labelled chitosan was synthesized according to the methodology described by our research group previously (Cook, 2011). $\mathrm{CaCl}_{2}$ was purchased from Fisher Scientific UK Limited. The microbiology media Man, Rogosa and Sharpe (MRS) broth, agar, and phosphate-buffered saline (PBS) were purchased from Oxoid (Basingstoke, UK). Pectin solutions and chitosan solution were purified by microfiltration $(0.45 \mu \mathrm{m}$, Minisart filter, Sartorius Stedim, Biotech). All other reagents and materials were sterilized in an autoclave $\left(121^{\circ} \mathrm{C}, 15 \mathrm{~min}\right)$. Lactobacillus casei NCIMB 30185 (PXN 37) strain was received from Probiotics International Ltd (Protexin) (Somerset, UK). 


\subsection{Culture preparation}

Lactobacillus casei NCIMB 30185 (1XN37) was spread onto MRS agar from a cell bank and was incubated at $37^{\circ} \mathrm{C}$ for $48 \mathrm{~h}$. A colony was picked and inoculated into MRS broth (10 mL) and incubated at $37{ }^{\circ} \mathrm{C}$ for $24 \mathrm{~h}$ to get a bacterial suspension with an $\mathrm{OD}_{600}$ of approximately 2.0. After growth the cells were separated by centrifugation for $10 \mathrm{~min}\left(3200 \mathrm{rpm}\right.$, at $\left.4^{\circ} \mathrm{C}\right)$, the supernatant was collected, the cell pellet was rinsed with $1 \mathrm{~mL}$ PBS and redispersed in $10 \mathrm{~mL}$ pectin solution to give approximately $6 \times 10^{9} \mathrm{CFU} / \mathrm{mL}$.

\subsection{Preparation of unloaded pectin capsules}

Unloaded (without L. casei) pectin capsules were prepared using an extrusion method. 1, 2, and $3 \mathrm{w} / \mathrm{v} \%$ pectin aqueous solutions $(1 \mathrm{~mL})$ were extruded with a syringe $(0.8 \mathrm{~mm}$ diameter needle $)$ and a pump (flow rate set at $2 \mathrm{~mL} \mathrm{~min}^{-1}$ ) into $50 \mathrm{~mL} 0.15 \mathrm{M} \mathrm{CaCl}_{2}$. Gel beads were formed upon contact with $\mathrm{CaCl}_{2}$, and were left to harden for $30 \mathrm{~min}$. The distance from the surface of the solution and the needle was $10 \mathrm{~cm}$. After hardening, the pectin gel beads were removed from the solution via filtration. Chitosan coated capsules were prepared by dispersing pectin gel beads in $10 \mathrm{~mL}$ chitosan solution $(0.4 \%$ w/v in $0.1 \mathrm{M}$ acetic acid; $\mathrm{pH}$ set to 6 using $1 \mathrm{M}$ microfiltered $\mathrm{NaOH}$,) under gentle stirring for 10 minutes and then subsequently were removed by filtration.

\subsection{Production of probiotic containing pectin capsules}

In order to produce probiotic containing capsules, the L. casei suspension was mixed with 3\% amidated pectin solution (1:9 volume ratio) and the capsules were generated by extrusion and coated as described above. The viability and bacteria release studies are described in terms of quantity of extruded pectin (each batch of capsules corresponds to $1 \mathrm{~mL}$ of extruded pectin solution).

2.5 Morphology of the capsules prepared from grades of pectin

The morphology of the gel beads prepared using various types and different concentrations of pectin $(1,2$, and $3 \mathrm{w} / \mathrm{v} \%$ of amidated, low methyl ester and high methyl ester pectins) was evaluated with a light microscope (Leica DM2500). Gel beads were examined under ×1.6-2.5 magnification. 
The diameters of uncoated beads were determined with a light microscope (Leica DM2500) and using an image analysis software (ImageJ). The compressive strength was determined using Texture Analyser (Stable Microsystems, UK), with a $\mathrm{P} \backslash 1 \mathrm{~K}$ steel probe at $1 \mathrm{~mm} \mathrm{~s}^{-1}$ rate, with $0.01 \mathrm{~N}$ trigger force.

2.7 Viability of Lactobacillus casei in simulated gastric juice (SGJ)

For non-encapsulated bacteria, L. casei was inoculated in MRS broth $(10 \mathrm{~mL})$ and the culture incubated at $37^{\circ} \mathrm{C}$ for 24 hours. It was then separated by centrifugation for $10 \mathrm{~min}$ at $4{ }^{\circ} \mathrm{C}(3200 \mathrm{rpm})$; the bacteria were collected and rinsed with PBS $(1 \mathrm{~mL})$. Following the incubation, a $1 \mathrm{~mL}$ aliquot was taken to evaluate the initial cell concentration using the spread plating method. Cells were diluted with PBS, and $0.1 \mathrm{~mL}$ of the appropriate dilution was spread onto MRS agar. Plates were incubated at 37 ${ }^{\circ} \mathrm{C}$ for $48 \mathrm{~h}$ and the colony forming units (CFU) were determined. To evaluate cell survival in gastric conditions, SGJ (10 mL, pH 2.0) was added to cells and incubated at $37^{\circ} \mathrm{C}$ with shaking at $100 \mathrm{rpm}$. After $15 \mathrm{~min}, 30 \mathrm{~min}, 60 \mathrm{~min}$ and $120 \mathrm{~min}$ intervals an aliquot $(1 \mathrm{~mL})$ of the SGJ was diluted in $9 \mathrm{~mL}$ PBS and enumerated using spread plating method described above.

For encapsulated bacteria, 3 batches with L. casei were prepared from the same broth of cells. Two of these batches were transferred into SGJ and incubated at $37{ }^{\circ} \mathrm{C}$ with shaking at $100 \mathrm{rpm}$. The third batch was transferred into $100 \mathrm{~mL}$ of PBS and incubated for $1 \mathrm{~h}$ at $37^{\circ} \mathrm{C}$ with shaking at 100 rpm. These batches were then homogenized in Seward stomach 400 circulator for $20 \mathrm{~min}$ at $230 \mathrm{rpm}$ ) and enumerated to give the initial bacteria concentration. The two batches of beads in the SGJ were removed after 1 and $2 \mathrm{~h}$ of incubation. These beads were placed into $100 \mathrm{~mL}$ of PBS and incubated for $1 \mathrm{~h}$ at $37{ }^{\circ} \mathrm{C}$ with shaking at $100 \mathrm{rpm}$. Then the beads were dissolved and enumerated using the methods described above.

\subsection{Release of bacteria from capsules}

The release of bacteria from the capsules was studied during 120 min of incubation the capsules in SGJ for $2 \mathrm{~h}\left(\mathrm{pH} 2.0,10 \mathrm{~mL}\right.$ at $37^{\circ} \mathrm{C}$ with shaking at $\left.100 \mathrm{rpm}\right)$; then these were removed via filtration and placed into simulated intestinal juice for $3 \mathrm{~h}\left(\mathrm{pH} 7.2,100 \mathrm{~mL}\right.$ at $37^{\circ} \mathrm{C}$ with shaking at 
$100 \mathrm{rpm}$ ). Then this mixture was transferred into Seward stomach 400 circulator for $20 \mathrm{~min}$ (230 rpm) and the bacteria counted by taking $1 \mathrm{~mL}$ aliquots. $1 \mathrm{~mL}$ aliquots were also taken after 1 and 2 hours in SGJ and after 1 and 2 hours in SIJ in order plot the bacteria release profiles. The enumeration of viable bacteria was performed the spread plating method.

\subsection{Determination of coat thickness using fluorescent microscopy}

The thickness of the chitosan coat was determined by fluorescent microscopy using a Leica DM2500 microscope. The lyophilized FITC-chitosan was dissolved in $0.1 \mathrm{M}$ acetic acid to form $0.4 \%$ (w/v) solution, with $\mathrm{pH}$ adjusted to 6.0 using $1 \mathrm{M} \mathrm{NaOH}$. This was then used to coat pectin beads as described in section 2.3. The bead images were taken using a Leica DM2500 fluorescent stereomicroscope. The thickness of coating layer was determined using ImageJ.

\subsection{Statistical analysis}

Statistical analysis was conducted with a two-tailed unpaired Student's t-test and $p<0.05$ was considered as significant.

\section{Results and discussion}

\subsection{Morphology, diameter and texture properties of beads}

The influence of pectin concentration on the formation of gel beads was initially investigated. Three different types of pectin were studied as potential materials to form calcium pectinate gel capsules (amidated pectin, low methyl pectin and high methyl pectin). It was observed that the extrusion of these solutions into $0.15 \mathrm{M} \mathrm{CaCl}_{2}$ results in the formation of gel beads of different shape and it depends on the type of pectin used as well as the concentration of its solution (Fig. 1). More spherical beads are formed upon increasing the polymer concentration, which is possibly related to an increase in solution viscosity. 


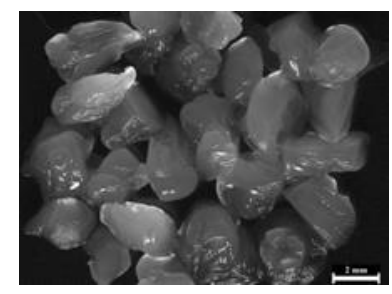

$1 \%$ low methyl pectin

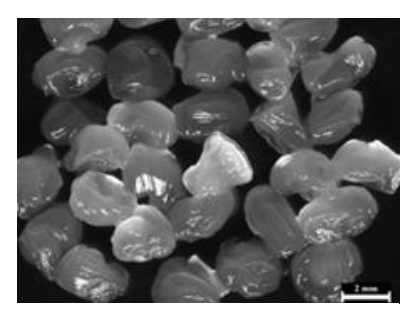

$1 \%$ amidated pectin

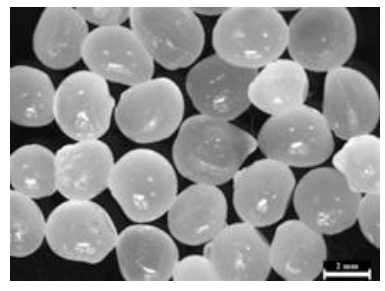

$2 \%$ low methyl pectin

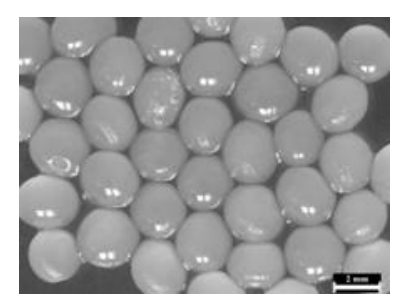

$2 \%$ amidated pectin

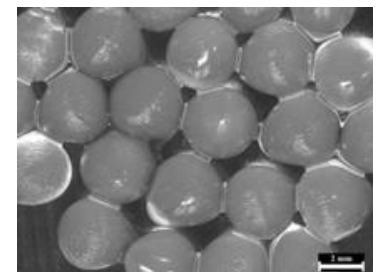

$3 \%$ low methyl pectin

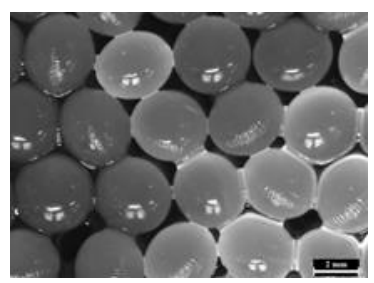

$3 \%$ amidated pectin

Fig.1. Morphology of capsules prepared with different types and concentration of pectin. A 1.6$2.5 \times$ magnification was used. The scale bar represents $2 \mathrm{~mm}$.

It was noted that encapsulation with $1 \%(\mathrm{w} / \mathrm{v})$ pectin does not give a spherical shape to the capsules. Furthermore, when $1 \%(\mathrm{w} / \mathrm{v})$ high methyl pectin was used it was observed that capsule formation did not occur. This can be due to the fact that the gelling properties of pectin depend on the degree of esterification (Soumya \& Suvendu, 2012). It was previously reported that high methyl pectins will form gel in the presence of sugars or other small molecules (e.g. polyols or monohydric alcohols) (Oakenfull \& Scott, 1984; Thakur, Singh \& Handa, 1997), and at low pH (3.0-4.5). Additionally, gelation of low methyl pectins takes place solely in the presence of divalent cations such as calcium (Soumya \& Suvendu, 2012).

Table 1 presents a summary of the key physicochemical characteristics (diameter and compressive strength) of the gel beads from the different pectins used. Note that size and mechanical strength were characterised only for spherical beads.

Table 1. Physical characteristics of pectin beads

\begin{tabular}{lllll}
\hline Polymer & $\begin{array}{l}\text { Concentration, } \\
\%(\mathrm{w} / \mathrm{v})\end{array}$ & $\begin{array}{l}\text { Compressive } \\
\text { strength, } \mathrm{N}\end{array}$ & $\begin{array}{l}\text { Diameter of } \\
\text { beads, mm }\end{array}$ & Comments \\
\hline Low methyl pectin & 1 & - & - & Capsules are not spherical \\
High methyl pectin & 1 & - & - & Do not form capsules \\
Amidated pectin & 1 & - & - & Capsules are not spherical \\
Low methyl pectin & 2 & $2.12 \pm 0.34$ & $2.57 \pm 0.02$ & Spherical capsules
\end{tabular}




$\begin{array}{lllll}\text { High methyl pectin } & 2 & - & - & \text { Do not form capsules } \\ \text { Amidated pectin } & 2 & 8.88 \pm 0.57 & 2.76 \pm 0.01 & \text { Spherical capsules } \\ \text { Low methyl pectin } & 3 & 3.32 \pm 0.29 & 3.47 \pm 0.03 & \text { Spherical capsules } \\ \text { Amidated pectin } & 3 & 9.37 \pm 0.56 & 3.50 \pm 0.05 & \text { Spherical capsules } \\ \text { High methyl pectin } & 3 & - & - & \text { Do not form capsules }\end{array}$

As expected, it was found that with increasing the concentration of pectin, the size and mechanical strength of the capsules also increased. Amidated pectin also formed mechanically stronger capsules compared to low methyl ester pectin at the same polymer concentration. According to the literature (Chandramouli and others 2004; Sabikhi and others 2010; Hansen and others 2002) larger capsules typically provide better protection to cells towards adverse environmental conditions. Spheres with size ranges between 1 and $3 \mathrm{~mm}$ are preferably used in immobilised cell technology applications (Heidebach and others 2012). Anal and Singh (2007) also stated that the large size of bacteria (typically 1-4 $\mu \mathrm{m}$ ) is a serious challenge for cell encapsulation. These dimensional characteristics limit cell loading in small capsules, and in the case that larger capsules they will have suboptimal textural and sensorial properties in food products. Muthukumarasamy et al. (2006) established that larger capsules (2-4 mm) improved the viability of Lactobacillus reuteri compared to smaller capsules $(20-1000 \mu \mathrm{m})$. Chandramouli et al. (2004) also demonstrated that the viability of lactobacilli in simulated gastric conditions was greater for alginate capsules of larger size (200-1000 $\mu \mathrm{m})$. Due to their larger size and greater mechanical strength, amidated pectin $(3 \%(\mathrm{w} / \mathrm{v}))$ was selected

\subsection{Viability of non-encapsulated Lactobacillus casei in SGJ}

The viability of free $L$. casei in SGJ ( $\mathrm{pH} \mathrm{2.0)} \mathrm{was} \mathrm{evaluated} \mathrm{to} \mathrm{establish} \mathrm{if} \mathrm{these} \mathrm{cells} \mathrm{were} \mathrm{acid}$ resistant. After 60 minutes of SGJ exposure a reduction in cell viability of $1 \log$ was observed (Fig. 2) and after 120 min even greater decrease in cell numbers of approximately 5 logs was seen, giving a final cell recovery of $10^{5} \mathrm{CFU} / \mathrm{mL}$. This indicates that $L$. case $i$ is sensitive to the acidic environment in the stomach and there is a need for an encapsulation system to protect L. casei cells during its gastrointestinal delivery. 


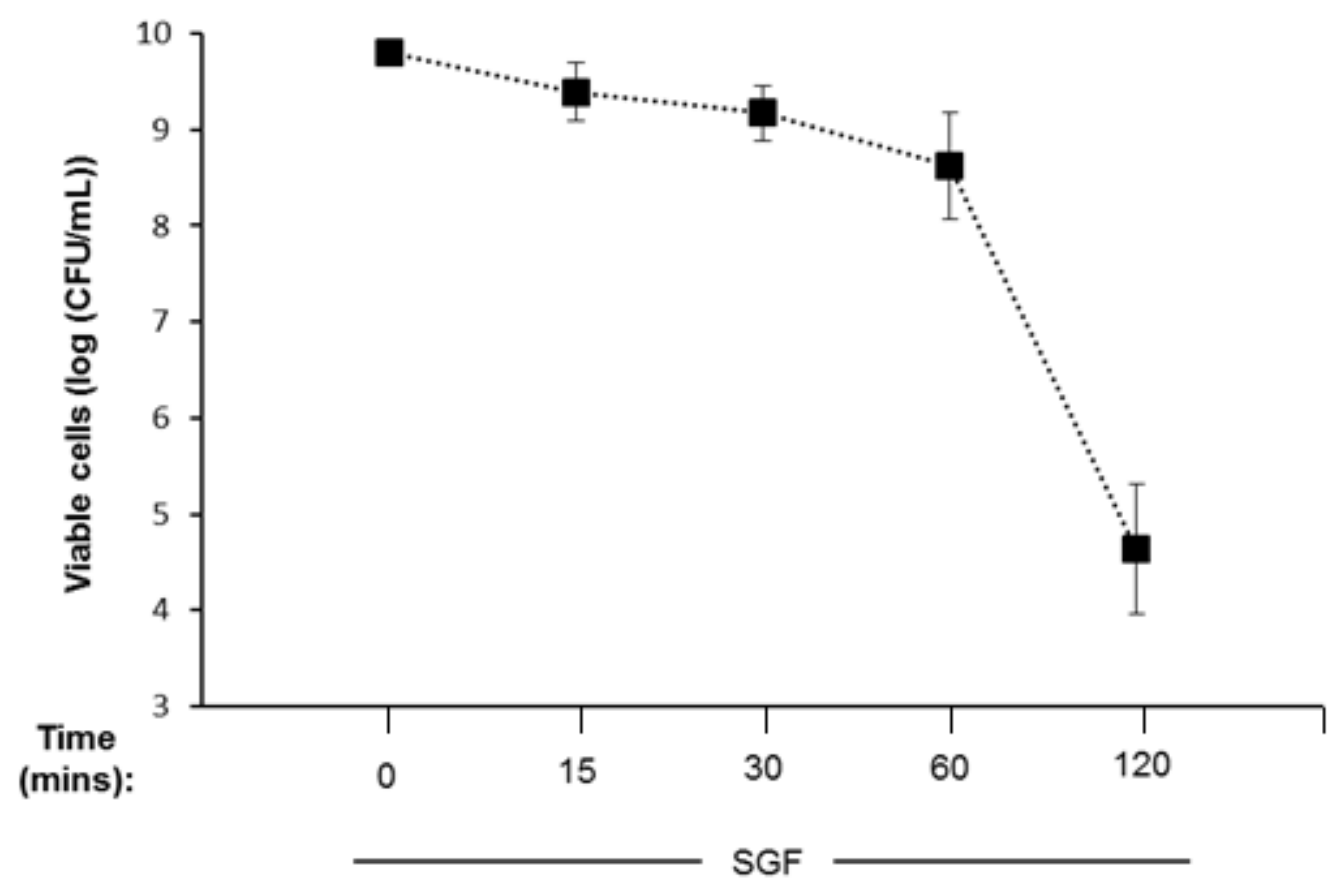

Fig.2. Viability of free Lactobacillus casei in SGJ (pH 2.0), n=3.

3.3 Viability of Lactobacillus casei during its encapsulation into calcium pectinate beads and subsequent coating with chitosan on the viability of L. case $i$ were investigated. It was established that the encapsulation process resulted in approximately $0.3 \log \mathrm{CFU} / \mathrm{mL}$ reduction in cell viability (Fig.3). However, there was no loss in viability associated with the coating process. A similar small $\operatorname{loss}(\sim 0.4 \log \mathrm{CFU} / \mathrm{mL})$ was previously observed for the encapsulation of B. breve into calcium alginate beads (Cook and others 2011) and was related to dissolution of the capsules rather than the encapsulation itself.

It is well known that chitosan has antimicrobial properties (Rabea and others 2003) and its direct contact with live bacteria could potentially result in reduction of their viability. In order to establish how deeply chitosan macromolecules can penetrate into calcium pectinate gel, experiments were performed with FITC-chitosan using fluorescent microscopy. Fig.4 shows a fluorescent image of calcium pectinate bead coated with FITC chitosan. The bright green band responsible for the fluorescence of FITC-chitosan indicates that the depth of penetration of chitosan macromolecules into calcium pectinate gel within 10 min exposure was around $0.236 \pm 0.061 \mathrm{~mm}$. This result indicates that 
chitosan likely forms a coating on the surface of pectinate gels and does not penetrate deeply into calcium pectinate. However, this penetration of chitosan into pectinate gel is greater compared to its penetration into calcium alginate gels, reported in our previous publication (Cook and others 2011), where around $0.007 \mathrm{~mm}$ penetration depth was observed. The difference between permeability of these two gel materials presents some interest for further studies.

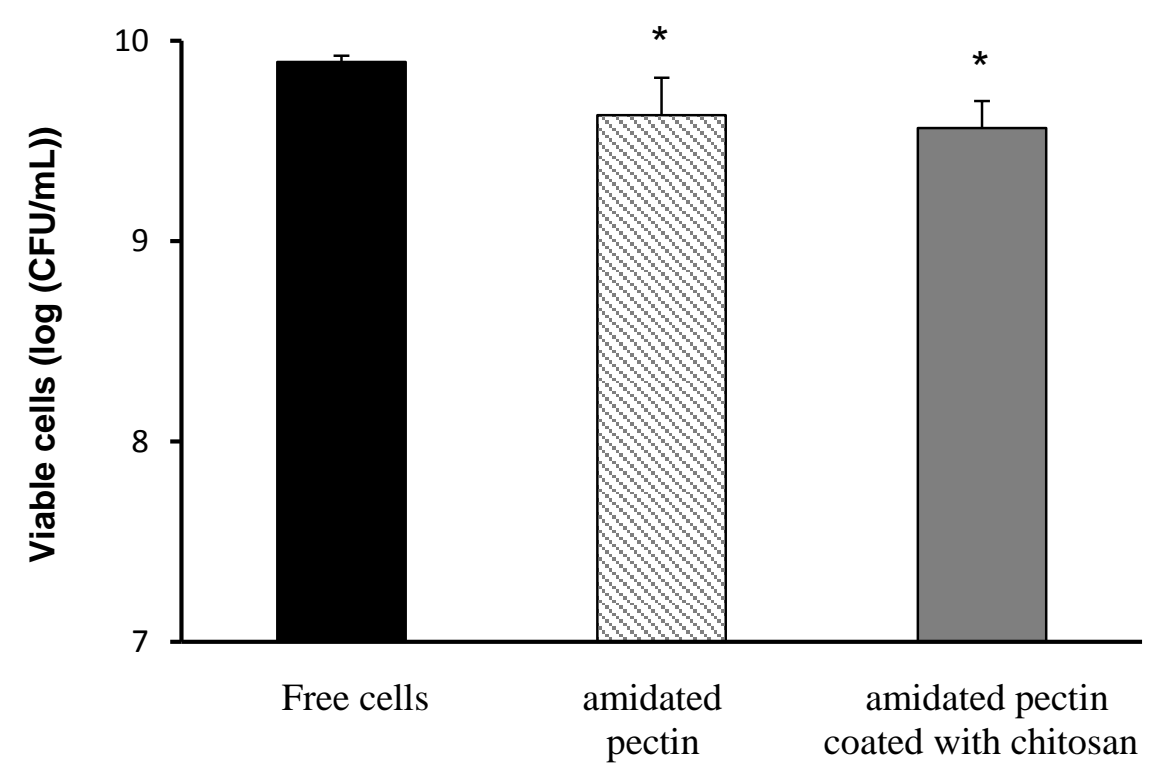

Fig.3. Viability of Lactobacillus casei during the encapsulation process: a) free cells, b) cells encapsulated into 3\% calcium pectinate, c) cells encapsulated into 3\% calcium pectinate with chitosan coating. Amidated pectin was used in these experiments $(\mathrm{n}=5) . p$ values denoted by $*(p<0.05)$, signifies statistical difference when compared to free cells.

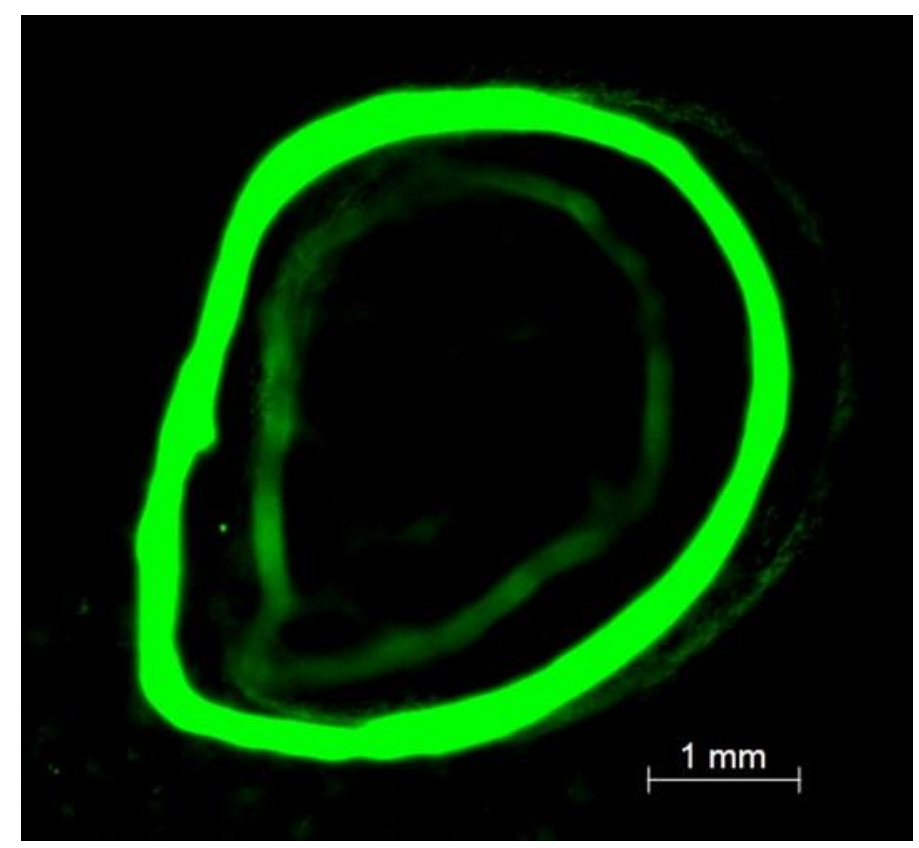


Fig.4. Fluorescent microscopy image showing penetration of FITC-chitosan (green) into calcium pectinate capsule.

\subsection{Viability of encapsulated Lactobacillus casei in SGJ (pH 2.0)}

Previous studies (Gebara and others 2013; Chotiko and others, 2016) indicated the usefulness of pectin-based materials for encapsulation of various probiotics and highlighted the need for using protective coatings to improve bacteria viability.

Calcium pectinate beads prepared from $3 \%$ amidated pectin without and with chitosan coating were evaluated under simulated gastric conditions ( 2 hours at $\mathrm{pH} 2.0$ ) to study the effect of encapsulation on the protection to probiotics from the low $\mathrm{pH}$ in the stomach. After 120 min of exposure to acidic $\mathrm{pH}$, coated capsules showed very high viability of bacteria without any significant ( $>0.05$ ) drop in the levels of live cells for up to $120 \mathrm{~min}$. The viability of cells residing within the uncoated beads dropped to less than $7 \operatorname{logs} \mathrm{CFU} / \mathrm{mL}$ within $60 \mathrm{mins}$ and then to less than $4 \operatorname{logs}$ CFU/mL within 120 mins. Crucially, after 2 hours in simulated gastric conditions the coated capsules showed no loss in cell viability, resulting in a cell recovery of $9.6 \operatorname{logs} \mathrm{CFU} / \mathrm{mL}$, which proves that a pectin chitosan coated system effectively protects the cells in a very acidic environment. This also suggests that chitosan coating alone is responsible for total acid protection. The protective effect observed due to chitosan, a basic polysaccharide, is likely to be because of the ability of this polysaccharide to neutralize $\mathrm{H}^{+}$ions penetrating into the beads, i.e. chitosan coat acts as a buffering layer preventing acid ingress (Cook et al. 2013). Moreover, it was reported by us previously (Cook et al, 2011) that chitosan-coated alginate beads offered weaker protection compared to chitosan coated pectinate. However, to better understand the protection mechanism, the interaction between pectin and chitosan has to be studied further. 


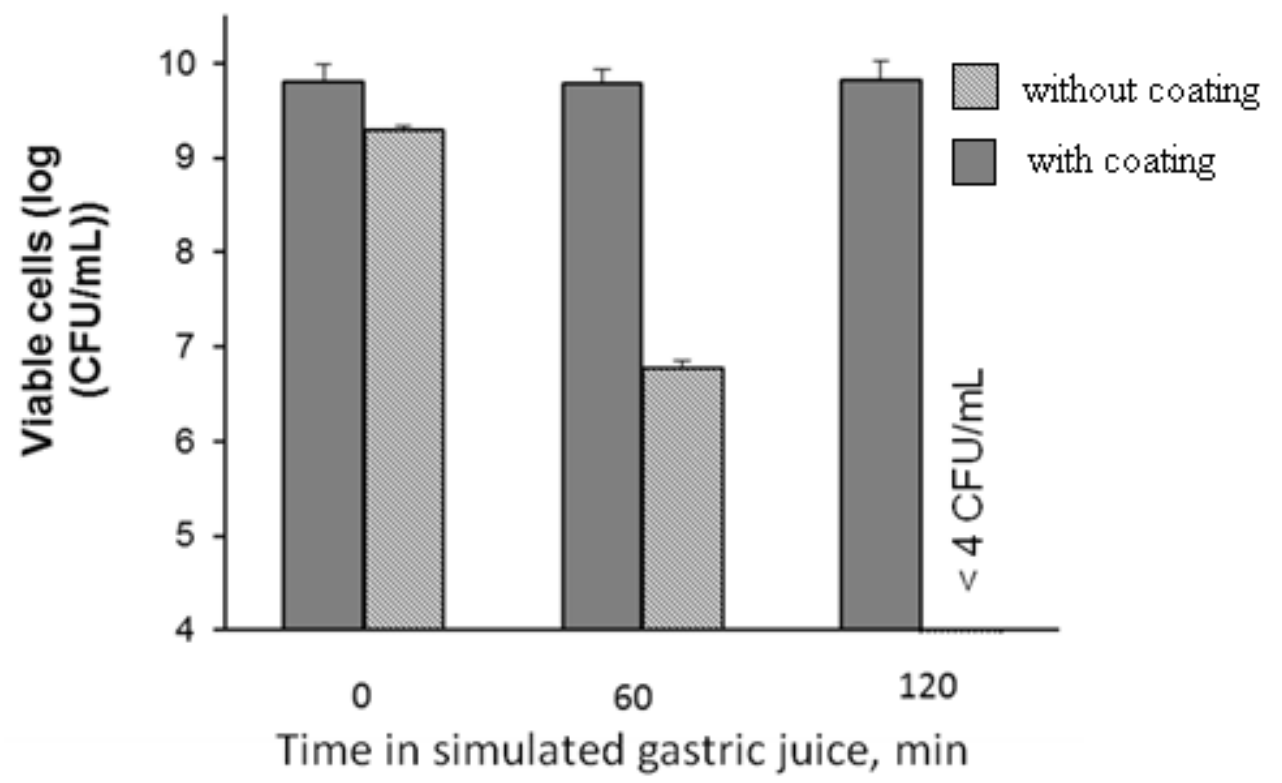

\subsection{Release of encapsulated bacteria in simulated intestinal juice (SIJ)}

In order to be effective as enteric delivery system, the capsules must preserve the viability of the probiotic cells during their transit through the stomach and deliver these cells alive and in high numbers in the intestine (Suita-Cruz \& Goulet, 2001).

As the produced pectin-chitosan coated capsules provided good results in the acid challenge test, their ability to deliver cells to the intestine was investigated. In this in vitro experiment, gastrointestinal passage was simulated by exposing the capsules to low $\mathrm{pH}$ in the stomach during 2 hours, followed by exposure to the high $\mathrm{pH}$ encountered in the intestine for 3 hours. The main aim of this experiment was to understand the release profile of the bacteria in the GI tract. It was observed that no cells were recovered during gastric transit, but crucially after 1 hour of transferring to SIJ a quick release effect was seen and a complete cell recovery was achieved (Fig.6). Disintegration of the pectinate capsules and release of bacteria in SIJ observed in this study is in accordance with the literature for similar systems. For example, Gebara et al (2013) have also reported complete disintegration of pectin microparticles coated with whey protein at $\mathrm{pH}$ 7.0. This disintegration is related to the dissociation of pectin-chitosan polyelectrolyte complex coating (Birch et al, 2014) as well as calcium pectinate gel (Günter and others 2016) under these $\mathrm{pH}$ conditions. 

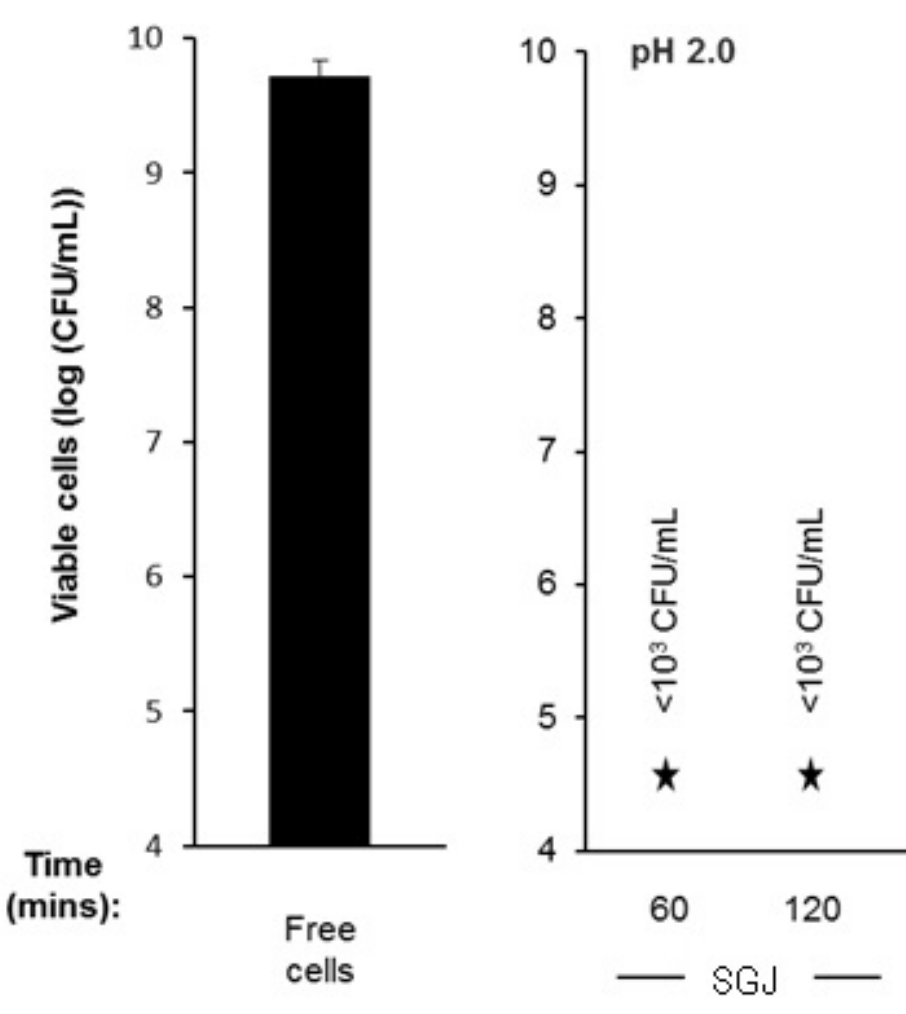

Transferred

Fig.6. Release of Lactobacillus casei after exposure to SGJ (2 h) and SIJ (3 h), n=4.

\section{Conclusion}

Hydrated calcium pectinate capsules containing live $L$. casei were produced using the extrusion technique and were subsequently coated with chitosan. Pectin capsules without chitosan coat were found to provide limited protection to L. casei in simulated gastric juice. Coating with chitosan effectively protected the bacterial cells from the acid in the simulated gastric juice and intestinal juice, suggesting that these capsules are suitable for gastrointestinal delivery of viable cells. In the future, the evaluation of sensory characteristics of these capsules will be of interest.

\section{Acknowledgements}

365 This work was funded by the grant from the Ministry of Education and Science, Republic of Kazakhstan under the project "Developing immunostimulating dairy products with encapsulated synbiotics" (grant number 0115РК01199). The authors also acknowledge Shakarim State University of Semey (Kazakhstan) for providing additional funding to support this project. 


\section{References}

Albadran H, Chatzifragkou A, Khutoryanskiy VV, Charalampopoulos D. 2015. Stability of probiotic Lactobacillus plantarum in dry microcapsules under accelerated storage conditions. Food Research International 74: 208-16.

Anal AK, Singh H. 2007. Recent advances in microencapsulation of probiotics for industrial applications and targeted delivery. Trends in Food Science \& Technology 18: 240-51.

Belitz HD, Grosch W, Schieberle P. 2004. Carbohydrates. In Food Chemistry, 245-339. Berlin, Germany: Springer.

Birch NP, Schiffman JD. 2014. Characterization of Self-Assembled Polyelectrolyte Complex Nanoparticles Formed from Chitosan and Pectin. Langmuir 30: 3441-447.

Burgain J, Gaiani C, Linder M, Scher J. 2011. Encapsulation of probiotic living cells: From laboratory scale to industrial applications. Journal of Food Engineering 104: 467-83.

Chandramouli V, Kailasapathy K, Peiris P, Jones M. 2004. An improved method of microencapsulation and its evaluation to protect Lactobacillus spp. in simulated gastric conditions. Journal of Microbiological Methods, 56: 27-35.

Chotiko A, Sathivel S. 2016. Three protective agents for pectin-rice bran capsules for encapsulating Lactobacillus plantarum. Food Bioscience, 16: 56-65.

Cook M, Tzortzis G, Charalampopoulos D, Khutoryanskiy VV. 2011. Production and Evaluation of Dry Alginate - Chitosan Microcapsules as an Enteric Delivery Vehicle for Probiotic Bacteria. Biomacromolecules, 12: 2834-840.

Cook MT, Tzortzis G, Charalampopoulos D, Khutoryanskiy VV. 2012. Microencapsulation of probiotics for gastrointestinal delivery. Journal of Controlled Release, 162: 56-67.

Cook MT, Saratoon T, Tzortzis G, Edwards AD, Charalampopoulos D, Khutoryanskiy VV. 2013. A CLSM method for the dynamic observation of $\mathrm{pH}$ change within polymer matrices for oral delivery. Biomacromolecules, 14: 387-93.

Cook MT, Tzortzis G, Khutoryanskiy VV, Charalampopoulos D. 2013. Layer-by-layer coating of alginate matrices with chitosan-alginate for the improved survival and targeted delivery of probiotic bacteria after oral administration. Journal of Materials Chemistry. B, 1: 52-60.

Gebara C, Chaves KS, Ribeiro MCE, Souza FN, Grosso CRF, Gigante ML. 2013. Viability of Lactobacillus acidophilus La5 in pectin-whey protein microparticles during exposure to simulated gastrointestinal conditions. Food Research International, 51: 872-78. 
Gerez CL, Font de Valdez G, Gigante ML, Grosso CR. 2012. Whey protein coating bead improves the survival of the probiotic Lactobacillus rhamnosus CRL 1505 to low $\mathrm{pH}$. Letters in Applied Microbiology, 54: 552-56.

Günter EA, Popeyko OV. 2016. Calcium pectinate gel beads obtained from callus cultures pectins aspromising systems for colon-targeted drug delivery. Carbohydrate Polymers, 147: 490-99.

Hansen LT, Allan-Wojtas PM, Jin YL, Paulson AT. 2002. Survival of Ca-alginate microencapsulated Bifidobacterium spp. in milk and simulated gastrointestinal conditions. Food Microbiology, 19: 35-45.

Heidebach T, Först P, Kulozik U. 2012. Microencapsulation of Probiotic Cells for Food Applications. Critical Reviews in Food Science and Nutrition, 52: 291-11.

Morris G, Kök S, Harding S, Adams G. 2010. Polysaccharide drug delivery systems based on pectin and chitosan. Biotechnol Genet Eng Rev, 27: 257-84.

Muthukumarasamy P, Holley RA. 2006. Microbiological and sensory quality of dry fermented sausages containing alginate-microencapsulated Lactobacillus reuteri. International Journal of Food Microbiology, 111: 164-169.

Nualkaekul S, Cook MT, Khutoryanskiy VV, Charalampopoulos D. 2013. Influence of encapsulation and coating materials on the survival of Lactobacillus plantarum and Bifidobacterium longum in fruit juices. Food Research International, 53: 304-11.

Oakenfull D, Scott A. 1984. Hydrophobic interaction in the gelation of high methoxyl pectins. Journal of Food Science, 49: 1093-98.

Pliszczak D, Bourgeois S, Bordes C, Valour JP, Mazoyer MA, Orecchioni AM, Nakache E, Lantéri P. 2011. Improvement of an encapsulation process for the preparation of pro- and prebioticsloaded bioadhesive microparticles by using experimental design. European Journal of Pharmaceutical Sciences, 44: 83-92.

Rabea EI, Badawy ME-T, Stevens CV, Smagghe G, Steurbaut W. 2003 Chitosan as Antimicrobial Agent: Applications and Mode of Action, Biomacromolecules, 4: 1457-465.

Reid G. 2016. Probiotics: definition, scope and mechanisms of action. Best Practice \& Research Clinical Gastroenterology, 30: 17-25.

Sabikhi L, Babu R, Thompkinson DK, Kapila S. 2010. Resistance of microencapsulated Lactobacillus acidophilus LA1 to processing treatments and simulated gut conditions. Food and Bioprocess Technology, 3: 586-93.

Sandoval-Castilla O, Lobato-Calleros C, García-Galindo HS, Alvarez-Ramírez J, Vernon-Carter EJ. 2010. Textural properties of alginate-pectin beads and survivability of entrapped Lb. casei in simulated gastrointestinal conditions and in yoghurt. Food Research International 43: 111-17. 
Shi LE, Li ZH, Li DT, Xu M, Chen HY, Zhang ZL, Tang ZX. 2013. Encapsulation of probiotic Lactobacillus bulgaricus in alginate-milk microspheres and evaluation of the survival in simulated gastrointestinal conditions. Journal of Food Engineering, 117: 99-104.

Shori AB. 2017. Microencapsulation Improved Probiotics Survival During Gastric Transit. HAYATI Journal of Biosciences 24: 1-5.

Siuta-Cruce P, Goulet J. 2001. Improving probiotic survival rates: microencapsulation preserves the potency of probiotic microorganisms in food systems. Food Technology, 55: 36-42.

Soumya B, Suvendu B. 2012. Food Gels: Gelling Process and New Applications, Critical Reviews in Food Science and Nutrition. Food Gels and Application, 52: 334-46.

Thakur BR, Singh RK, Handa AK, Rao MA. 1997. Chemistry and uses of pectin - A review. Critical Reviews in Food Science and Nutrition, 37: 47-73.

.

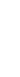

